\title{
RESEARCH OF QUALITATIVE INDICATORS OF BUTTER COOKIES USING PROTEIN-MINERAL SUPPLEMENTS
}

\author{
Iryna Kholobtseva \\ Dnipro State Agrarian and Economic University \\ 25 Serhii Efremov str., Dnipro, Ukraine, 49600 \\ Maksym Serik $₫$ \\ serikmax82@gmail.com \\ Olga Samokhvalova \\ ${ }^{1}$ Kharkiv State University of Food Technology and Trade \\ 333 Klochkivska str., Kharkiv, Ukraine, 61051
}

$\triangle$ Corresponding author

\begin{abstract}
The results of researches of influence of protein-mineral supplements on quality indicators of butter cookies are presented. It is described, that the supplements are used as a multifunctional ingredient, which on the one hand enriches the finished product with digestible calcium compounds, on the other - performs a number of technological tasks and improves the consumer characteristics of butter cookies.

The purpose of the study was to determine the effect of protein-mineral supplements on a number of physicochemical, consumer characteristics and safety indicators of butter cookies.

The study of the following physicochemical parameters of the quality of butter cookies was conducted: mass fraction of moisture, wettability, alkalinity, calcium content, including total and protein-bound.

It is established, that with the content of supplements up to $5.0 \%$ of the flour weight, all the above indicators meet the established requirements. With the content of suppements at the level of $6.0 \ldots 7.0 \%$, there are limit values of such an indicator as wettability, which is undesirable to ensure the appropriate porous structure of the product. Based on the obtained data, it can be stated, that $5.0 \%$ of the use of supplements is the limit rational content in the composition of butter cookies.

The organoleptic analysis proved the high characteristics of the developed products in comparison with traditional ones. In products with supplements, there was an improvement in the structure of the product in the cut and its color. This is ensured by the stabilization of the emulsion by the supplement during the manufacture of products and by peculiarities of its chemical composition.

Studies of safety indicators allowed to establish less intensive dynamics of accumulation of primary oxidation products (peroxides) in samples of flour and butter products with supplements in comparison with control. The best microbiological stability of products with supplements is also proved. Due to the bacteriostatic effect of the supplements, less intensive accumulation of microflora during storage was achieved.

On the basis of the conducted researches the expediency of using up to $5.0 \%$ of protein-mineral supplements in the composition of flour and butter products for enrichment of finished products with digestible calcium compounds, improvement of organoleptic characteristics and safety indicators have been established.
\end{abstract}

Keywords: protein-mineral supplement; calcium compounds; butter cookies; quality improvement; food safety.

DOI: $10.21303 / 2504-5695.2021 .001968$

\section{Introduction}

The food industry, including confectionery, in modern developed countries is in constant development, due to the expansion of the product range.

This effect is achieved mainly due to the introduction of the following measures: the use of new raw materials [1-5], by-products of food production of plant [6] and animal origin [7, 8]; enrichment of finished products with essential compounds. The most common way of enrichment is the introduction of biologically active supplements of natural [9-11] and microbiological origin into 
the product [12]. The use of these measures makes it possible not only to expand the variety of finished products, but also to create products for functional and health purposes. This direction is relevant, as the lack of macro-and micronutrients, vitamins and other nutrients is a common problem of nutrition.

The aim of the work is to study the qualitative characteristics of butter cookies, enriched with digestible calcium compounds [13]. As an enriching component, it is proposed to use a protein-mineral supplement and an improved protein-mineral supplement [14]. Supplements have a powdery state, cream color, are characterized by neutral organoleptic quality indicators.

In terms of chemical composition, they are partially thermally hydrolyzed collagen proteins, which are a matrix for the formation of chelate complexes with calcium and magnesium. In supplements, calcium compounds are in two states: chelate complexes and calcium citrate. This allows, on the one hand, to ensure the deposition of calcium in the tissues due to the high metabolic activity of chelate complexes and to maintain the level of calcium in the consumer's blood due to citrates. The improved form of the supplement contains chondroitin sulfates, which have pronounced complexing properties and are an important metabolic factor that ensures efficient absorption of calcium compounds and its deposition in tissues [14].

Research of qualitative characteristics of functional and health-improving products is an expedient element of development of the specified products. This is due to the fact that the introduction of new components in the formulation of products can, on the one hand, have a positive effect on their nutritional and biological value, and on the other - negatively affect the standard indicators of their quality.

Thus, in order to determine the effect of protein-mineral supplements and improved protein-mineral supplements on the quality of butter cookies, it is necessary to solve the following tasks:

1) to investigate the effect of supplements on the normative physicochemical characteristics of butter cookies;

2) to determine the effect of supplements on the organoleptic characteristics of the finished product;

3) to investigate the change in the safety of the developed cookies during storage.

\section{Materials and methods}

The object of the study is samples of butter cookies with the addition of protein-mineral supplement (PMS) and improved protein-mineral supplement (IPMS) [14]. Supplements were added to the product in the amount of $1.0 \ldots 7.0 \%$ of the weight flour. Samples of cookies, made according to the recipe without supplements, served as controls.

The supplement is a powder system based on partially hydrolyzed collagen tissues of animal origin, which are the basis for the sorption of calcium and magnesium cations and the formation of stable chelate complexes on their surface.

Total chemical composition of PMS ( \%): moisture $-6.1 \pm 0.2$; protein $-75.5 \pm 2.75 \%$; fat $-8.1 \pm 0.4$; chondroitin sulfates $-0.2 \pm 0,005$; ash $-10.1 \pm 0.4$; calcium $-7.5 \pm 0.4$; magnesium $0.35 \pm 0.02$. Total chemical IPMS ( \%): moisture $-6.2 \pm 0.2$; protein $-60.2 \pm 2.5 \%$; fat $-6.5 \pm 0.3$; chondroitin sulfates $-19.0 \pm 1.0$; ash $-8.1 \pm 0.3$; calcium $-6.7 \pm 0.35$; magnesium $-0.31 \pm 0.02$.

The share of such protein-bound calcium reaches $60 \ldots 65 \%$ of its total amount, $35 \ldots$ $40 \%$ of calcium is represented by citrate, which has a low metabolic activity, but is able to effectively maintain the level of calcium in the blood of consumers. The powder has a neutral taste and aromatic characteristics, cream color, which provides a wide range of supplements in food technology. The improved form of the supplement contains up to $20.0 \%$ of chondroitin sulfates. They are known to be an important factor in the absorption of calcium by the human body and are capable of forming colloidal solutions with high viscosity. This provides their technological functionality [14].

Organoleptic, physicochemical indicators of quality of baked samples of cookies, safety indicators, in particular oxidative transformations of lipids and microbiological indicators were investigated. 
Organoleptic quality indicators of the studied samples were determined on the basis of expert assessments $[15,16]$, humidity - by drying to the constant weight [15], alkalinity - by titration [16]. The wettability of cookies was determined by the ratio of the weight of the batch before and after immersion in water [16], the total calcium content - by burning a batch of cookies and titrimetrically [17]. The content of protein-bound calcium was determined by the author's method with sequential determination of mineral and organically bound calcium [17].

Determination of the number of mesophilic aerobic and facultative anaerobic microorganisms, as well as the number of mold fungi by inoculation on a nutrient medium, followed by direct counting of colonies. Determination of the content of bacteria of the Escherichia coli group and pathogenic microflora by inoculation on an accumulation medium, followed by re-inoculation on a differential diagnostic medium and identification of microorganisms. Acid, iodine and peroxide numbers were determined titrimetrically with prior extraction of the fat fraction [17].

The samples were made according to the traditional recipe and technology with the appropriate preparation of the supplement and the replacement of a certain portion of wheat flour for it [18].

\section{Research results and their discussion}

In accordance with the purpose of the work, a number of studies were conducted to determine the physical and chemical quality indicators that are normalized for cookies, and consumer characteristics of new products, made using protein-mineral supplements. At the first stage the conformity of wettability, humidity, alkalinity of finished products to the established requirements was investigated. The content of total and protein-bound calcium was also evaluated as an important criterion for assessing the quality of the target product. The research results are given in Table $\mathbf{1 .}$

Table 1

The research results of physicochemical quality indicators of butter cookies $(n=5, p \leq 0.05)$

\begin{tabular}{|c|c|c|c|c|}
\hline \multirow[b]{2}{*}{ Sample } & \multicolumn{4}{|c|}{ Indicator } \\
\hline & $\begin{array}{c}\text { Mass share of mois- } \\
\text { ture, } \%\end{array}$ & Wettability, \% & $\begin{array}{c}\text { Alkalinity, } \\
\text { degrees }\end{array}$ & $\begin{array}{c}\text { Content of calcium } \\
\text { Total/protein-bound, } \mathrm{mg} / 100 \mathrm{~g}\end{array}$ \\
\hline Standard & No more 15.50 & No less 110 & No more 2.0 & - \\
\hline Control & 7.82 & 170 & 1.4 & $34 / 2$ \\
\hline \multicolumn{5}{|c|}{ Cookies with PMS } \\
\hline $1.0 \% \mathrm{PMS}$ & 7.92 & 158 & 1.42 & $74 / 46$ \\
\hline $2.0 \% \mathrm{PMS}$ & 8.05 & 149 & 1.47 & $112 / 71$ \\
\hline $3.0 \% \mathrm{PMS}$ & 8.21 & 142 & 1.55 & $158 / 98$ \\
\hline $4.0 \%$ PMS & 8.32 & 132 & 1.58 & $197 / 119$ \\
\hline $5.0 \% \mathrm{PMS}$ & 8.54 & 127 & 1.62 & $235 / 145$ \\
\hline $6.0 \%$ PMS & 8.76 & 113 & 1.69 & $282 / 170$ \\
\hline $7.0 \%$ PMS & 8.93 & 108 & 1.75 & $317 / 197$ \\
\hline \multicolumn{5}{|c|}{ Cookies with IPMS } \\
\hline $1.0 \%$ IPMS & 8.12 & 162 & 1.45 & $68 / 44$ \\
\hline $2.0 \%$ IPMS & 8.32 & 154 & 1.49 & $98 / 63$ \\
\hline $3.0 \%$ IPMS & 8.54 & 149 & 1.54 & $125 / 79$ \\
\hline $4.0 \%$ IPMS & 8.78 & 139 & 1.57 & $167 / 105$ \\
\hline $5.0 \%$ IPMS & 8.96 & 130 & 1.63 & $205 / 127$ \\
\hline $6.0 \%$ IPMS & 9.04 & 118 & 1.68 & $254 / 158$ \\
\hline $7.0 \%$ IPMS & 9.22 & 112 & 1.72 & 297/182 \\
\hline
\end{tabular}

Based on the obtained data, it can be stated, that when using up to $5 \%$ of PMS and $7 \%$ of IPMS, the finished product meets the established requirements for moisture content, wettability, alkalinity. When the content of the supplement is $5 . .7 \%$, the maximum content of digestible calcium compounds is naturally observed.

It should be noted, that at the content of supplements at the level of $6 . .7 \%$ there are limit values of such an indicator as wettability. This is an important characteristic of sensory perception of a buttery flour product, which characterizes the porosity of the structure and the ability of the 
components to hydrate. Low wettability can be an indicator of crumbly structure loss by products. Thus, on the basis of the obtained data it can be stated, that $5 \%$ of the use of supplements is the limit rational content in the composition of flour products.

At the next stage, the organoleptic characteristics of the developed products with $5 \%$ content of the supplements were determined. It is established, that the product samples are characterized by the following organoleptic characteristics, given in Table 2 and Fig. 1.

Table 2

The organoleptic quality indicators of butter cookies

\begin{tabular}{ccc}
\hline Standard & Cookies with PMS 5\% & Cookies with IPMS 5\% \\
\hline Surface & The surface is smooth without cracks and damage & The surface is smooth without cracks and damage \\
Color & From light cream to light brown & From light cream to light brown \\
Taste and smell & Inherent in recipe components. & No foreign smells and smacks \\
Outlook in the cut & The cookies are evenly baked. Porous structure. & No foreign smells and smacks \\
& There are single cavities & The cookies are evenly baked. Porous structure.
\end{tabular}

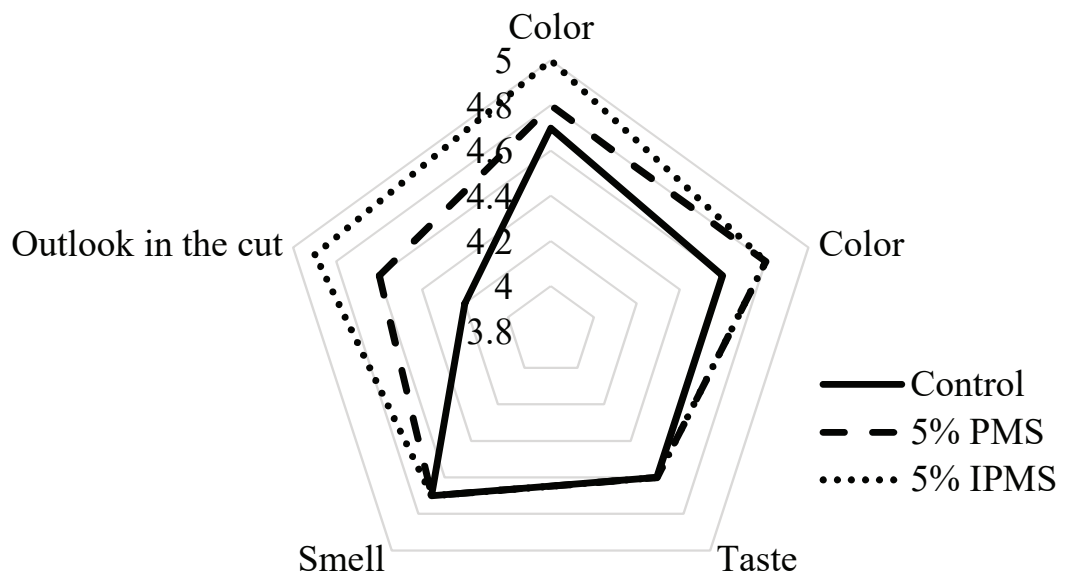

Fig. 1. The results of expert organoleptic evaluation of butter flour products taking into account the weighting factors

Fig. 1 shows that products, containing $5.0 \%$ of IPMS, have the best organoleptic characteristics. The main advantages of this product are the uniform structure in the cut, the formation of a smoother surface of the product and improved color characteristics. The uniformity of the structure is achieved by obtaining a more stable emulsion system with IPMS in the manufacture of buttery products, which ensures the uniform distribution of the fat phase.

Thus, it is possible to form the uniform porous structure without large differences in the size of cavities. The advantages in the formation of color are the presence in the composition of supplements of a significant proportion of thermally hydrolyzed proteins, which during heat treatment are able to interact with carbohydrates and, as a consequence - the formation of stained substances. The color becomes more saturated and expressive, which has a positive effect on the external perception of the product without the use of additional color-forming recipe ingredients.

At the next stage, the safety indicators of the developed products during storage were investigated. Storage was performed at a temperature of $18 \pm 3{ }^{\circ} \mathrm{C}$, relative humidity not more than $75.0 \%$, for 90 days in a film polypropylene non-hermetic package. The dynamics of acid, iodine and peroxide values were studied in order to determine the nature of the accumulation of primary products of lipid oxidation. The research results are presented in Fig. 2-4.

The obtained results indicate that the samples of flour butter products with the supplement are characterized by less pronounced dynamics of oxidative processes. This is due to the fact that the supplement contains calcium citrate, which has antioxidant properties and is able to prevent the 
development of chain reactions of lipid oxidation and prevent the accumulation of peroxides. It has been found, that the use of PMS in this aspect is more effective. This is due to the higher content of calcium citrate compared to the improved form of the supplement.

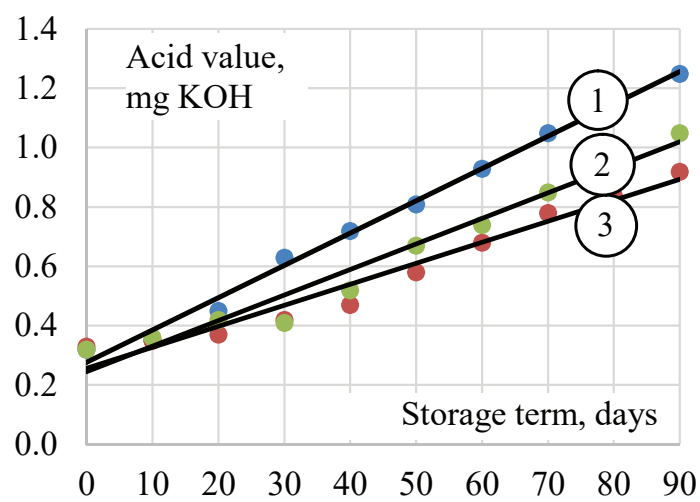

Fig. 2. Dynamics of changes in acid value during storage of butter cookies:

1 - control; $2-5 \%$ of IPMS; $3-5 \%$ of PMS

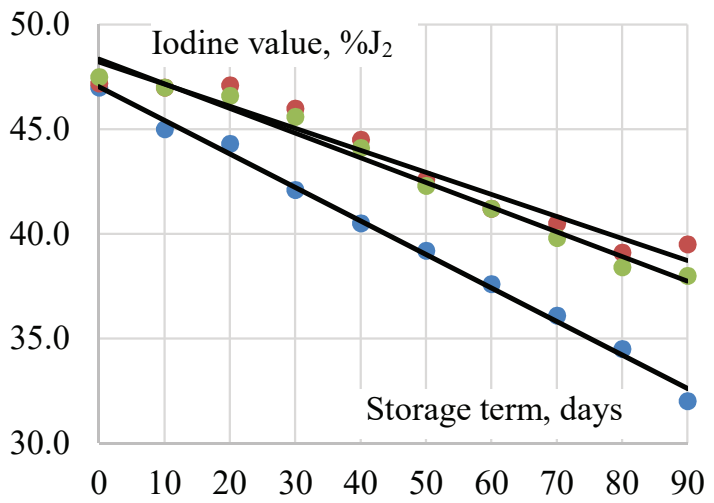

Fig. 3. Dynamics of changes in iodine value during storage of butter cookies:

1 - control; $2-5 \%$ of IPMS; 3 - $5 \%$ of PMS

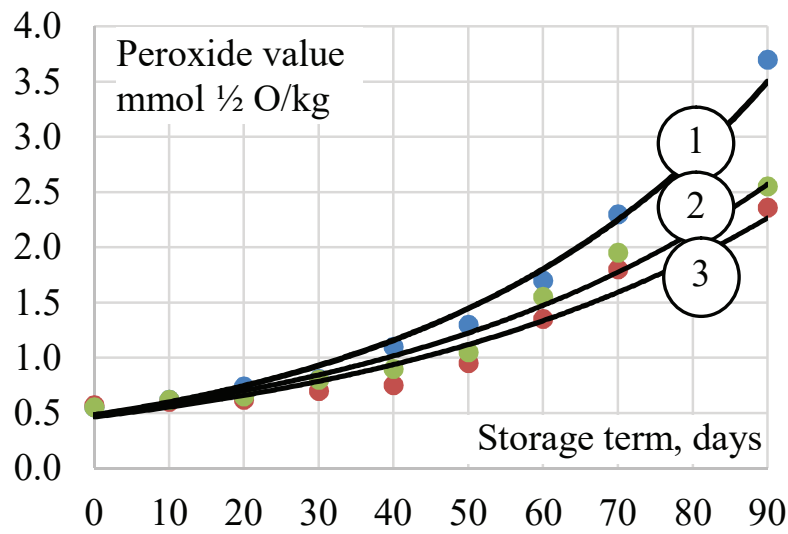

Fig. 4. Dynamics of changes in peroxide value during storage of butter cookies:

1 - control; $2-5 \%$ of IPMS; $3-5 \%$ of PMS

The results of studies of microbiological safety indicators are given in Table 3 .

As a result of the research of microbiological quality indicators it has been established, that supplements are characterized by the expressed bacteriostatic character. The dynamics of the 
QMAFAnM, which is an indicator of total microbial contamination of the product, proves to inhibit the development of microorganisms in comparison with the control product. Given the low humidity of the product, the accumulation of microflora can occur due to its ingress mainly from the external environment. However, provided that all samples were stored under the same conditions, samples with supplements show microbiological stability. This is caused by the preservative action of calcium citrate, which prevents the development of vegetative forms of microorganisms.

Table 3

The research results of microbiological quality indicators of butter cookies $(n=5, \mathrm{p} \leq 0.05)$

\begin{tabular}{|c|c|c|c|c|c|}
\hline \multirow{2}{*}{\multicolumn{2}{|c|}{ Quality indicators }} & \multicolumn{4}{|c|}{ Samples } \\
\hline & & $\begin{array}{l}\text { Standard } \\
\text { values }\end{array}$ & $\begin{array}{l}\text { Butter cook- } \\
\text { ies (control) }\end{array}$ & $\begin{array}{c}\text { Butter cookies } \\
\text { with } 5 \% \text { of PMS }\end{array}$ & $\begin{array}{c}\text { Butter cookies } \\
\text { with } 5 \% \text { of IPMS }\end{array}$ \\
\hline \multirow{3}{*}{$\begin{array}{c}\text { QMAFAnM* }(\mathrm{CFU} / \mathrm{g}, \text { no more }) \\
\text { before and after storage }\end{array}$} & 0 days $* *$ & & $5.7 \times 10^{2}$ & $3.2 \times 10^{2}$ & $3.0 \times 10^{2}$ \\
\hline & 45 days $* *$ & $1 \times 10^{4}$ & $6.5 \times 10^{2}$ & $3.4 \times 10^{2}$ & $3.3 \times 10^{2}$ \\
\hline & 90 days** & & $8.2 \times 10^{2}$ & $3.4 \times 10^{2}$ & $3.6 \times 10^{2}$ \\
\hline \multirow{3}{*}{\multicolumn{2}{|c|}{$\begin{array}{c}\text { Bacteria of the Escherichia coli group (coli-forms) in } 0.1 \mathrm{~g} \\
\text { Pathogenic m/o including Salmonella, in } 25 \mathrm{~g} \\
\text { Mold fungi, CFU, in } 1 \mathrm{~g}\end{array}$}} & Not permitted & Not detected** & Not detected ${ }^{* *}$ & Not detected** \\
\hline & & Not permitted & Not detected $* *$ & Not detected ${ }^{* *}$ & Not detected** \\
\hline & & Not permitted & Not detected $* *$ & Not detected** & Not detected** \\
\hline
\end{tabular}

The absence of Escherichia coli bacteria and pathogenic microflora indicates a high sanitary level of raw materials and compliance with sanitary and hygienic requirements in the production of the final product.

Thus, flour and butter products, made using $5.0 \%$ of protein-mineral supplements, are characterized by better safety indicators compared to products, made by the traditional technology. This may be a certain competitive advantage of the developed technology compared to existing analogues at the market.

\section{Conclusions}

As a result of solving these problems, we can conclude that the use of protein-mineral supplements in the technology of production of butter cookies in the amount of $5.0 \%$ of the flour weight allows:

- to improve the mineral composition of the finished products, in particular to enrich them with digestible calcium compounds, and effectively improve their consumer characteristics;

- to ensure compliance with regulatory requirements for such physical and chemical quality indicators as wettability, humidity, alkalinity of the finished products to the established regulatory requirements;

- to improve the organoleptic characteristics of the products through the formation of the more homogeneous porous structure and more intense color of the finished product;

- to improve the safety of the new products compared to traditional products throughout the shelf life by inhibiting oxidative processes in lipids and inhibiting the development of microflora.

The obtained results will allow the implementation of the developed technology of butter cookies in production. This will help improve the market for functional and health food products. At the next stage, medical and biological studies of the effectiveness of the use of this product to compensate for calcium deficiency in consumers will be organized.

\section{References}

[1] Novikova, N. V., Kamienieva, R. S. (2020). Use of non-traditional raw materials to improve the consumption properties of wax based cakes. Vestnyk Khersonskoho natsyonalnoho tekhnycheskoho unyversyteta, 2 (73), 48-53. doi: http://doi.org/10.35546/ kntu2078-4481.2020.2.5

[2] Dorohovych, V. (2020). Flour confectionery products for people with diabetes with the use of products from processing carrots. Scientific Works of National University of Food Technologies, 26 (1), 238-244. doi: http://doi.org/10.24263/2225-2924-2020-26-1-28 
[3] Brito, T. B. N., R.S. Lima, L., B. Santos, M. C., A. Moreira, R. F., Cameron, L. C., C. Fai, A. E., S. L. Ferreira, M. (2021). Antimicrobial, antioxidant, volatile and phenolic profiles of cabbage-stalk and pineapple-crown flour revealed by GC-MS and UPLC-MSE. Food Chemistry, 339, 127882. doi: http://doi.org/10.1016/j.foodchem.2020.127882

[4] Moro, T. M. A., Celegatti, C. M., Pereira, A. P. A., Lopes, A. S., Barbin, D. F., Pastore, G. M., Clerici, M. T. P. S. (2018). Use of burdock root flour as a prebiotic ingredient in cookies. LWT, 90, 540-546. doi: http://doi.org/10.1016/j.lwt.2017.12.059

[5] De Oliveira, L. M., da Silva Lucas, A. J., Cadaval, C. L., Mellado, M. S. (2017). Bread enriched with flour from cinereous cockroach ( Nauphoeta cinerea ). Innovative Food Science \& Emerging Technologies, 44, 30-35. doi: http://doi.org/10.1016/ j.ifset.2017.08.015

[6] Kasabova, K. R., Grevtseva, N. V., Shidakova-Kamenyuka, O. G., Omelchenko, O. V. (2017). Use of the secondary products of wineries and breweries production the technology of butter biscuits. Equipment and Technologies of Food Production, 35 , 5-11. Available at: http://elibrary.donnuet.edu.ua/id/eprint/1449

[7] Malison, A., Arpanutud, P., Keeratipibul, S. (2021). Chicken foot broth byproduct: A new source for highly effective peptide-calcium chelate. Food Chemistry, 345, 128713. doi: http://doi.org/10.1016/j.foodchem.2020.128713

[8] Y1lmaz, V. A., Koca, İ. (2020). Development of gluten-free corn bread enriched with anchovy flour using TOPSIS multi-criteria decision method. International Journal of Gastronomy and Food Science, 22, 100281. doi: http://doi.org/10.1016/ j.ijgfs.2020.100281

[9] Waheed, M., Butt, M. S., Shehzad, A., Adzahan, N. M., Shabbir, M. A., Rasul Suleria, H. A., Aadil, R. M. (2019). Eggshell calcium: A cheap alternative to expensive supplements. Trends in Food Science \& Technology, 91, 219-230. doi: http://doi.org/ 10.1016/j.tifs.2019.07.021

[10] Patiño-Rodríguez, O., Bello-Pérez, L. A., Agama-Acevedo, E., Pacheco-Vargas, G. (2020). Pulp and peel of unripe stenospermocarpic mango (Mangifera indica L. cv Ataulfo) as an alternative source of starch, polyphenols and dietary fibre. Food Research International, 138, 109719. doi: http://doi.org/10.1016/j.foodres.2020.109719

[11] Das Chagas, E. G. L., Vanin, F. M., dos Santos Garcia, V. A., Yoshida, C. M. P., \& de Carvalho, R. A. (2020). Enrichment of antioxidants compounds in cookies produced with camu-camu (Myrciaria dubia) coproducts powders. LWT, 137, 110472. https://doi.org/10.1016/j.lwt.2020.110472

[12] Pavlotska, L. F., Dudenko, N. V., Tsyban, L. S. (2011). Vykorystannia mahnetytu dlia zmenshennia defitsytu zaliza v orhanizmi u skladi kondyterskykh vyrobiv. Prohresyvni tekhnika ta tekhnolohii kharchovykh vyrobnytstv restorannoho hospodarstva i torhivli, 2 (14), 239-244. Available at: https://elib.hduht.edu.ua/bitstream/123456789/3573/1/37.pdf

[13] Kholobtseva, I., Serik, M., Samohvalova, O. (2019). Improvement of the technology of a pastry semi-finished product enriched with digestable calcium compounds. Progressive technique and technologies of food production enterprises, catering business and trade, 2 (30), 35-47. doi: https://doi.org/10.5281/zenodo.3592825

[14] Cherevko, O. I., Mykhailov, V. M., Holovko, M. P., Holovko, T. M., Serik, M. L., Polupan, V. V., Bakirov, M. P. (2013). Naukovi osnovy tekhnolohii mineralizovanykh produktiv kharchuvannia. Ch. 3. Tekhnolohiia zbahachuvalnykh bilkovo-mineralnykh dobavok ta produktiv kharchuvannia ozdorovchoho pryznachennia z yikh vykorystanniam. Kharkiv: KhDUKhT, 165.

[15] Shydakova-Kameniuka, O. H., Rohova, A. L., Choni, I. V., Tereshchenko, M. V. (2020). Development of a technology for biscuit enriched with minerals. (2020). Scientific Bulletin of PUET: Technical Sciences, 1 (91), 62-70. doi: http://doi.org/ 10.37734/2518-7171-2019-1-8

[16] Lure, I. S., Skokan, L. E., Tsitovich, A. P. (2003). Tekhnokhimicheskiy i mikrobiologicheskiy kontrol v konditerskom proizvodstve. Moscow: Kolos, 416.

[17] Serik, M. L., Shurduk, I. V. (2018). Udoskonalennia tekhnolohii ta yakosti miasnykh emulsiinykh vyrobiv, zbahachenykh kaltsiiem. Kharkiv: KhDUKhT, 2018. Available at: https:/elib.hduht.edu.ua/bitstream/123456789/2821/1/ 2018 \% $\%$ D0 \%BF \%D0 \%BE \%D0 \%B7. \%20182.pdf

[18] Kholobtseva, I., Serik, M., Samohvalova, O. (2019). Improvement of the technology of a pastry semi-finished product enriched with digestable calcium compounds. Progressive technique and technologies of food production enterprises, catering business and trade, 2 (30), 35-47. doi: http://doi.org/10.5281/zenodo.3592825

How to cite: Kholobtseva, I., Serik, M., Samokhvalova, O. (2021). Research of qualitative indicators of butter cookies using protein-mineral supplements. EUREKA: Life Sciences, 4, 27-33. doi: https://doi.org/10.21303/2504-5695.2021.001968 